\title{
Pathogenicity of Fungi Associated with the Wheat Crown Rot Complex in Oregon and Washington
}

\author{
Richard W. Smiley, Professor, Jennifer A. Gourlie and Sandra A. Easley, Faculty Research Assistants, and \\ Lisa-Marie Patterson, Senior Faculty Research Assistant, Oregon State University, Columbia Basin Agricultural \\ Research Center, P.O. Box 370, Pendleton 97801
}

\begin{abstract}
Smiley, R. W., Gourlie, J. A., Easley, S. A., and Patterson, L.-M. 2005. Pathogenicity of fungi associated with the wheat crown rot complex in Oregon and Washington. Plant Dis. 89:949-957.

Crown rot of wheat in the Pacific Northwest is caused by a complex including Bipolaris sorokiniana, Fusarium avenaceum, F. culmorum, F. pseudograminearum, and Microdochium nivale. Relative pathogenicity was examined under greenhouse conditions for 178 isolates of the five species, and under field conditions for 24 isolates of $B$. sorokiniana, F. culmorum, and $F$. pseudograminearum. In the greenhouse, all five species reduced $(P<0.05)$ plant height relative to noninoculated controls. Disease severity was inversely correlated with plant height for the three Fusarium spp. In one or more of four experiments with spring wheat in the field, all three species reduced stand establishment and density of mature heads and increased the incidence and severity of crown rot. F. culmorum and F. pseudograminearum caused the greatest disease severity and plant damage and were the only pathogens that reduced grain yield. Virulence ratings were variable among isolates for each species in all greenhouse and field experiments. Isolate variability was especially high for the location and year variables in field experiments. Mixtures of multiple isolates are required for future research.
\end{abstract}

Additional keywords: Cochliobolus sativus, Triticum aestivum

A complex of crown- and root-infecting fungi causes chronic and occasionally severe damage to wheat (Triticum aestivum L.) and barley (Hordeum vulgare L.) in the Pacific Northwest (PNW) states of Idaho, Oregon, and Washington $(8,10)$. Primary pathogens in order of decreasing occurrence regionwide include Fusarium pseudograminearum (O'Donnell \& Aoki) $(=F$. graminearum group I = Gibberella coronicola), F. culmorum (Wm. G. Sm.) Sacc., Bipolaris sorokiniana (Sacc.) Shoemaker (= Cochliobolus sativus), $F$. avenaceum (Fr.:Fr.) Sacc. (= Gibberella avenacea), and Microdochium nivale (Fr.) Samuels \& I. C. Hallett (= Monographella nivalis) (29). These pathogens may occur singly but they often co-exist in the same fields and even within individual plants. Dominant species in the complex at a specific location can vary from year to year $(16,24,29)$, indicating a high level of adaptation as members of this pathogen com-

Corresponding author: R. Smiley

E-mail: richard.smiley@ oregonstate.edu

This research was funded by an Oregon State University subcontract to the USDA-Agricultural Research Service; SCA\#58-5348-9-100, "Control of Root Diseases of Wheat and Barley".

Accepted for publication 29 April 2005

DOI: 10.1094/PD-89-0949

(C) 2005 The American Phytopathological Society plex respond to changes in temperature, seasonal distribution, amount of moisture, and perhaps other edaphic factors (2$4,6,9,24)$. Although crown rot is chronic and damaging in the PNW (28), documentation of comparative damage caused by primary species and individual isolates in the crown rot complex has not been reported for the region.

The importance of individual crown rot pathogens in most regions of the world has been assessed by relative proportions of each pathogen isolated from symptomatic tissue $(2,8,16-18,26,29)$. Few studies have been conducted to evaluate the comparative virulence of crown rot pathogens under controlled or field conditions. In the eastern United States, using assays in the greenhouse and in a high-rainfall field environment $(935 \mathrm{~mm}$ of mean annual precipitation, with summer-dominant rainfall distribution pattern), Kane et al. (15) reported that single isolates of species associated with crown rot were highly variable in affecting wheat seedling mortality, plant tillering, plant growth, and yield. For instance, $F$. graminearum (= Gibberella zeae) caused more preemergence and post-emergence seedling death than $F$. avenaceum, whereas both species reduced tillering and grain yield. Brennan et al. (4) reported that F. culmorum and $F$. graminearum generally were more pathogenic than $F$. avenaceum and Microdochium nivale in retarding the rate of in vitro coleoptile elongation. Xue et al. (36) found a high degree of inter- and intraspecies variability in aggressiveness for multiple isolates of eight Fusarium spp. associated with Fusarium head blight, concluding that screening for resistance requires a mixture of isolates. Fernandez and Chen (13) evaluated multiple isolates of these pathogens for ability to cause crown rot and Fusarium head blight under controlled conditions. They found that $F$. culmorum and $F$. graminearum generally were more pathogenic than $F$. avenaceum. It was unknown whether the predominant crown rot pathogens in the PNW, especially $B$. sorokiniana, $F$. culmorum, and $F$. pseudograminearum, have similar variability among species and isolates. An understanding of these relationships is of particular importance under field conditions in the semiarid PNW wheat-belt, where seasonal precipitation averages 250 to 500 $\mathrm{mm}$ with a winter-dominant distribution pattern, and wheat maturation occurs during midsummer when high-temperature stress and diminishing availability of stored soil water often can become limiting to grain filling. The severity of crown rot damage to grain yield in the PNW is strongly influenced by plant stress near the end of the growing season (23).

The objective of this research was to compare relative pathogenicity to wheat for primary species of crown rot pathogens in the PNW. Plant growth and disease parameters were compared for inoculated and noninoculated soils in a greenhouse assay and in four field experiments performed with spring wheat over 2 years at two locations.

\section{MATERIALS AND METHODS}

Greenhouse experiments. Fungal isolates. Fungi associated with crown rot of winter wheat were collected during a survey of the disease in Oregon and Washington (29). Fungi initially were isolated from excised crown and subcrown internode tissues using peptone-pentachloronitrobenzene agar medium (22) and a modified Czapek-Dox agar medium containing benomyl at $10 \mu \mathrm{g} / \mathrm{ml}$ (30). These media are semiselective for Fusarium spp. and $B$. sorokiniana, respectively. Fungi initially were identified based on morphological features on 0.5 -strength potato-dextrose and wheat-leaf agar media (22). Identities of Fusarium spp. were confirmed using polymerase chain reaction procedures 
$(27,35)$. Isolates were stored on silica beads at $4^{\circ} \mathrm{C}$ and autoclaved barley seed at $-80^{\circ} \mathrm{C}$.

Inoculum was prepared by growing individual isolates on 0.2 -strength potatodextrose agar medium and transferring colonized agar blocks onto twiceautoclaved millet seed. Colonized millet was air dried, sieved to eliminate clumps, and stored at room temperature (approximately $24^{\circ} \mathrm{C}$ ) in paper bags.

Planting and management. Infestation of soil was achieved by placing inoculum above the wheat seed so the coleoptile would pass through the zone of infestation prior to seedling emergence $(11,33)$. A 15 $\mathrm{cm}$ layer of autoclaved commercial potting soil was placed into plastic "Ray Leach Super Cell Cone-tainers" (Stuewe \& Sons, Inc., Corvallis, OR), $3.8 \mathrm{~cm}$ in diameter by $21 \mathrm{~cm}$ in height. Four undamaged vernalized seed of 'Stephens' winter wheat were placed on the soil and covered with $2.5 \mathrm{~cm}$ of potting soil. Twenty millet seed were distributed over the soil surface and covered with an additional $2.5 \mathrm{~cm}$ of soil. The inoculum rate was optimal for moderate disease expression as determined by preliminary experimentation. Two replicate cone-tainers were used for each fungal isolate. Plants were watered to field capacity and incubated at temperatures of approximately 18 and $13^{\circ} \mathrm{C}$ (day and night, respectively) in the greenhouse regulated at an 8-h day length, using supplemental illumination from plant growth lights. All plants were watered to field capacity when drought symptoms first appeared in any of the pots.

Sampling. Plants were washed from soil 109 days after planting. Severity of infection for each of the eight plants per fungal isolate tested was assessed using a 0-to-7 rating scale, where $0=$ apparently healthy plant with no discoloration of any tissue; 1 = browning of scutellar node; $2=$ browning of scutellar node and either the subcrown internode or leaf sheath; 3 = living plant with browning of scutellar node, subcrown internode, and leaf sheaths; $4=$ dying plant with browning of subcrown internode, leaf sheaths, and lower culm; 5 $=$ dying plant with rotted culm base; $6=$ dead plant with rotted stem base (plants had matured to produce more than three leaves); and $7=$ plant death by rotting of seed or by pre-emergence damping-off of seedling. The height of the longest leaf tip above the soil surface was measured for each plant. The greenhouse assay was repeated using 10 control pots and 10 isolates for each fungus except for $M$. nivale, where only five isolates were available for testing.

Data analysis. Comparative effects of pathogen species on disease severity and plant height were analyzed with an analysis of variance using a completely randomized model with unbalanced numbers of replicates in the Co-Stat Statistical Soft- ware (version 6.101; CoHort Software, Monterey, CA). Individual fungal isolates were considered replicates for each species. Standard deviations and coefficients of variation were calculated as measures of variability among disease indices and plant heights for individual pathogen species. Means for pathogen treatments were separated using the Fisher's least significant difference test (LSD) when treatment effects were significantly different at $P<$ 0.05 .

Field experiments. Fungal isolates. Nonquantified native populations of the pathogens in soil were supplemented with inoculum of B. sorokiniana, F. culmorum, and $F$. pseudograminearum. Isolates were selected to achieve a range in both geographic origin and virulence ratings to wheat seedlings in greenhouse tests (as described above).

Five isolates of B. sorokiniana (9401201, 94096-03, 94097-07, 94103-18, and 94152-18) had virulence ratings of 3.6 to 6.5 on a 0 -to-7 scale in greenhouse tests and were from farms in Morrow County in Oregon and Adams, Lincoln, and Whitman Counties in Washington. Eight isolates of F. culmorum (93040-04, 93044-05, 9308907, 93094-11, 93103-10, 93113-05, 9311408, and 93130-03) had virulence ratings of 2.5 to 6.1 and were from farms in Sherman, Umatilla, and Wallowa Counties in Oregon and Adams, Lincoln, and Whitman Counties in Washington. Eleven isolates of $F$. pseudograminearum (94006-11, 94006-13, 94032-06, 93033-02, 93033-13, 93041-06, 94044-09, 94081-11, 94081-13, 93082-03, and 93093-04) had virulence ratings of 1.8 to 7.0 and were from farms in Sherman and Wasco Counties in Oregon and Lincoln and Walla Walla Counties in Washington.

Planting. Four field experiments were conducted with spring wheat $\mathrm{cv}$. Zak at the Oregon State University Columbia Basin Agricultural Research Center (CBARC) stations near Moro and Pendleton. Experiments were established on different fields at each location during 2003 and 2004. Soils in each of the four fields were Walla Walla silt loam (coarse-silty, mixed, superactive, mesic Typic Haploxerolls). Mean annual rainfall is $282 \mathrm{~mm}$ at CBARC-Moro and $442 \mathrm{~mm}$ at CBARCPendleton. Fields were prepared as conventionally tilled (chisel plow and rod weeder) summer fallow following winter wheat harvested during August 2001 or 2002, 19 months prior to planting spring wheat for these experiments during March 2003 or 2004. Soils in each field were naturally infested with a mixture of crown rot pathogens strongly dominated by $F$. pseudograminearum, as determined by isolations from infected wheat during previous years. Inoculum densities in soil were not quantified because the most important among the pathogens at these locations, $F$. pseudograminearum, survives as mycelium in pieces of crop refuse and is not readily quantified $(5,9,32)$.

Wheat seed not treated with a protectant fungicide was planted at $250 \mathrm{seed} / \mathrm{m}^{2}$ with a deep-furrow drill equipped with four shovel-type openers at a $36-\mathrm{cm}$ row spacing. Wheat at CBARC-Moro was planted at a depth of $3 \mathrm{~cm}$ and $10^{\circ} \mathrm{C}$ seed-zone temperature on 10 April 2003 and a depth of $4 \mathrm{~cm}$ and $9^{\circ} \mathrm{C}$ seed-zone temperature on 24 March 2004. Wheat at CBARCPendleton was planted at $2.5 \mathrm{~cm}$ of depth and a $6^{\circ} \mathrm{C}$ seed-zone temperature on 3 April 2003, and at $2 \mathrm{~cm}$ of depth and a $12^{\circ} \mathrm{C}$ seed-zone temperature on 23 March 2004. Standard fertilizer and weed control practices were utilized for each experiment.

Inoculum was prepared and stored as described for greenhouse experiments. The application rate of $2.3 \mathrm{~g}$ millet seed $/ \mathrm{m}$ of row (about $320 \mathrm{seed} / \mathrm{m}$ of row) was based on preliminary experiments with single isolates of each pathogen applied at seven rates from 0 to $8 \mathrm{~g} / \mathrm{m}$ of row, as described for F. pseudograminearum (28). Inoculum was placed manually about $2 \mathrm{~cm}$ above the wheat seed in two adjacent rows on one side of each four-row drill pass. The remaining two rows were used as controls, in which no millet seed was dispensed. One entire four-row drill pass in each experiment was not inoculated to determine whether there was evidence for transmission of inoculum from inoculated to noninoculated rows in other treatments. Inoculum was buried shallowly by raking soil laterally from between drill rows. Plots for fungus treatments and paired controls for each treatment were composed of one pair of rows over a 1.5-by-6-m area.

Experiments were designed as a split plot, with inoculation (plus or minus) as the main variable and pathogen species as the secondary variable. Isolates were considered replicates for each fungal species: 5 for B. sorokiniana, 8 for $F$. culmorum, and 11 for $F$. pseudograminearum.

Sampling. Plant emergence was measured as the number of plants $/ \mathrm{m}$ of row in one $1-\mathrm{m}$ row segment in each row 21 to 30 days after planting. Plants (10/plot) were collected, washed, and assessed for crown rot symptoms during late spring (June). Determinations were made for percentages of plants with brown discoloration (rotting) of internal crown tissue, percentages of plants with lesions on the subcrown internode, and severity of lesions on the subcrown internode ( 0 to 4 scale, where 0 $=$ no lesion and $4=$ severe necrosis). As plants matured during June, percentages of whiteheads (premature ripening of heads, usually with severely shriveled kernels) were estimated by counting whiteheads and total heads in each two-row plot. Numbers of heads per meter of row were calculated. All plots were harvested in July using a small-plot combine. Grain yields, test weights, and kernel weights were 
measured and calculated using standard equipment and procedures.

Data analysis. Data for each experiment were analyzed with an analysis of variance, using a split-plot design for the Co-Stat Statistical Software (version 6.101; CoHort Software). Means for pathogen species treatments were separated using the Fisher's LSD test when treatment effects were significantly different at $P<0.05$.

There were significant effects of inoculum for nearly all variables measured. There were no significant differences among the 26 control treatments in each split-plot experiment and, when the controls were paired with each pathogen treatment and analyzed using a randomized complete block model, no differences were detected among control treatments for any of the variables measured. Therefore, data for the four experiments were reanalyzed as a three-way randomized complete block design with location (Moro and Pendleton), year (2003 and 2004), and pathogen (control, B. sorokiniana, F. culmorum, and $F$. pseudograminearum) as main treatment effects. When treatment effects were significant at $P<0.05$, means were separated using the Fisher's LSD test. Additional analysis was performed in view of significant $(P<0.05)$ differences for all plant growth and yield parameters within the main treatment effects for year and location.

Data for each location were grouped over years and analyzed using the two-way randomized block model, in which year and pathogen treatment were evaluated as main effects, with 52 replicates for controls, 10 replicates for $B$. sorokiniana, 16 replicates for $F$. culmorum, and 22 replicates for $F$. pseudograminearum. Means for significant $(P<0.05)$ treatment effects were separated using the Fisher's LSD test.

For each of the four field experiments, effects of individual isolates for each species of crown rot pathogen were compared with a composite of control treatments for the experiment by using the standard error of the mean for that experiment.

\section{RESULTS}

Greenhouse experiments. Disease severity indices were increased $(P<0.05)$ and plant heights reduced when soils were infested with $B$. sorokiniana, $F$. avenaceum, F. culmorum, F. pseudograminearum, or M. nivale (Table 1). Disease indices generally were higher for Fusarium spp. than for B. sorokiniana and M. nivale. Rankings among species were the same in the second, abbreviated experiment (data not shown). Standard deviations and coefficients of variation increased with increasing mean disease severity and decreasing mean plant height (Table 1), indicating that variability among isolates increased with increasing mean aggressiveness.

Disease severity indices and plant heights were inversely correlated for the composite of all treatments $\left(P<0.0001, R^{2}\right.$ $=0.66, n=193)$ and for $F$. avenaceum $(P=$ $\left.0.0384, R^{2}=0.61, n=10\right), F$. culmorum $(P$ $\left.=0.0004, R^{2}=0.36, n=38\right)$, and F. pseu- dograminearum $\left(P<0.0001, R^{2}=0.56, n\right.$ $=108)$ but not for $B$. sorokiniana $(P=$ $\left.0.17, R^{2}=0.22, n=17\right)$, or $M$. nivale $(P=$ $0.06, R^{2}=0.94, n=5$ ). Regression curves for Fusarium spp. having significant correlations were of similar shape (Fig. 1) and differed mostly in the range for lower and upper values in the disease severity index (Table 1). Overall, pooling the data from isolates of $F$. pseudograminearum resulted in the highest measure of pathogenicity to wheat in the greenhouse.

Field experiments. Effect of location and season. Crops in these experiments received less-than normal rainfall during 2003 and more than or average rainfall during 2004. The 20-year mean annual rainfall during the 4-month spring wheat growing season (March to June) is 86 and $161 \mathrm{~mm}$ at Moro and Pendleton, respectively. The in-season rainfall at these locations was 54 and $127 \mathrm{~mm}$ during 2003 and 87 and $192 \mathrm{~mm}$ during 2004.

Plant growth, yield, and crown rot incidence and severity on seedlings were generally higher $(P<0.05)$ at Pendleton than

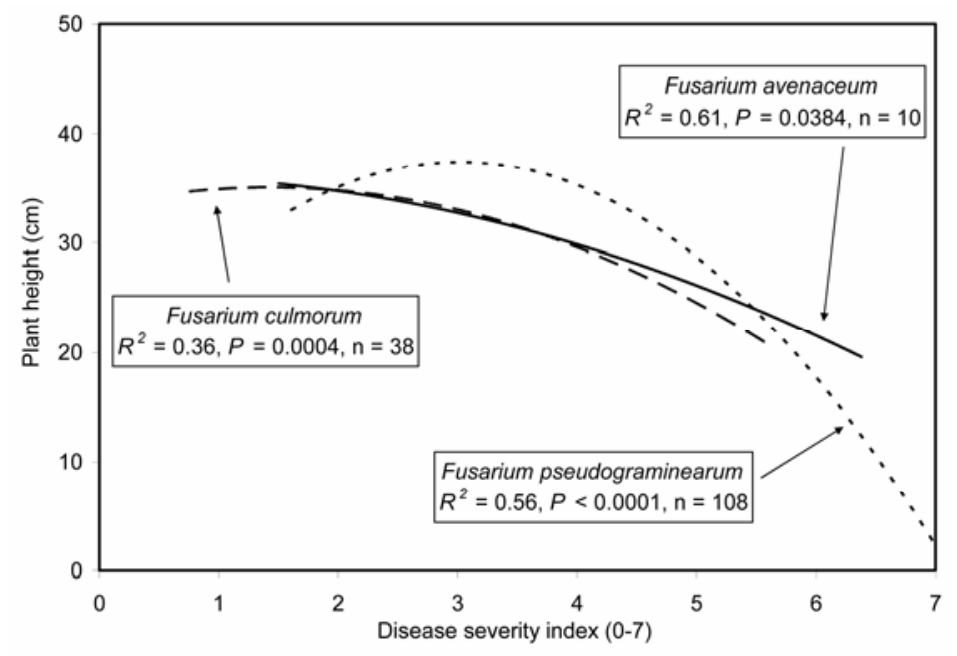

Fig. 1. Relationship between height of winter wheat cv. Stephens leaves and disease severity index (scale of 0 to 7 ) in soil infested with isolates $(n)$ of three crown rot pathogens in the greenhouse.

Table 1. Disease severity and height of 'Stephens' winter wheat plants in soil infested with 178 isolates of five crown rot pathogens compared to noninoculated controls in the greenhouse ${ }^{y}$

\begin{tabular}{|c|c|c|c|c|c|c|c|c|c|}
\hline \multirow[b]{2}{*}{ Inoculum treatment } & \multirow[b]{2}{*}{ No. of entries } & \multicolumn{4}{|c|}{ Disease severity $(0-7)^{z}$} & \multicolumn{4}{|c|}{ Plant height (cm) } \\
\hline & & Mean & Range & SD & CV & Mean & Range & SD & CV \\
\hline Control & 15 & $0.1 \mathrm{a}$ & $0-0.4$ & 0.1 & $\ldots$ & $45.3 \mathrm{a}$ & $42-48$ & 1.7 & 4 \\
\hline Bipolaris sorokiniana & 17 & $1.8 \mathrm{~b}$ & $0.6-3.1$ & 0.5 & 27 & $34.7 \mathrm{~b}$ & $28-39$ & 4.5 & 13 \\
\hline Microdochium nivale & 5 & $2.7 \mathrm{bc}$ & $0.9-4.5$ & 0.7 & 25 & $33.5 \mathrm{bc}$ & $28-42$ & 5.0 & 15 \\
\hline Fusarium culmorum & 38 & $3.7 \mathrm{~cd}$ & $0.8-5.6$ & 1.1 & 29 & $30.1 \mathrm{bc}$ & $20-41$ & 5.7 & 19 \\
\hline F. avenaceum & 10 & $4.4 \mathrm{~d}$ & $1.5-6.4$ & 1.4 & 34 & $27.7 \mathrm{bc}$ & $21-42$ & 7.2 & 26 \\
\hline F. pseudograminearum & 108 & $5.1 \mathrm{~d}$ & $1.6-7.0$ & 1.9 & 37 & $24.4 \mathrm{c}$ & $20-45$ & 11.5 & 47 \\
\hline $\mathrm{LSD}_{0.05}$ & $\ldots$ & 1.5 & $\ldots$ & $\ldots$ & $\ldots$ & 9.6 & $\ldots$ & $\ldots$ & $\ldots$ \\
\hline
\end{tabular}

y Means for control and inoculated treatments followed by the same letter within a column are not significantly different at $P=0.05$ according to Fisher's least significant difference (LSD) test. Each mean represents 8 test plants for each entry in each treatment; for instance, there were 120 plants ( 8 by 15$)$ in the control treatment. Each entry represents the number of isolates tested for each species of crown rot pathogen. $\mathrm{SD}=\mathrm{standard}$ deviation and $\mathrm{CV}=\mathrm{coeffi}-$ cient of variation expressed as a percentage.

${ }^{\mathrm{z}}$ Disease severity index: $0=$ apparently healthy plant with no discoloration of any tissue; $1=$ browning of scutellar node; $2=$ browning of scutellar node and either the subcrown internode or leaf sheath; 3 = living plant with browning of scutellar node, subcrown internode, and leaf sheaths; $4=$ dying plant with browning of subcrown internode, leaf sheaths, and lower culm; $5=$ dying plant with rotted culm base; $6=$ dead plant with rotted stem base (plants had matured to produce more than 3 leaves); and 7 = plant death by rotting of seed or by pre-emergence damping-off of seedling. 
at Moro (Table 2). Percentages of whiteheads were greater during 2003 (driest year) than 2004 (wettest year), and the density of mature heads and grain yields were higher during 2004 than 2003. Infesting soil with the three pathogen species did not cause significant differences in density of emerged seedlings or of mature heads but did lead to differences in all disease parameters and in grain yield. Each species caused the incidence of lesions to increase on subcrown internodes, with $F$. pseudograminearum having a greater effect than $B$. sorokiniana and F. culmorum. Severity of lesions on subcrown internodes and percentages of plants with rotted crowns were greater than for the control only in the $F$. pseudograminearum treatment. Both $F$. culmorum and $F$. pseudograminearum led to an increase in percentages of whiteheads in the maturing crop, and to yields lower than for the control.

Seedling stand. When data was grouped over years for each location, seedling stands were reduced $(P<0.05)$ by $F$. culmorum and $F$. pseudograminearum but not B. sorokiniana at Moro, and by none of the pathogens at Pendleton (Table 3). For individual experiments (data not shown), $B$. sorokiniana reduced stand at Moro during 2004 and Pendleton during 2003, F. culmorum reduced stand at Moro during 2004, and F. pseudograminearum reduced stand at Moro during both years and at Pendleton during 2004.
Diseases incidence and severity. For data grouped over years for each location, the incidence of subcrown internode lesions was increased by $F$. culmorum and $F$. pseudograminearum at Moro and by all three pathogens at Pendleton (Table 3). The main effect for year was not significant. For individual experiments, lesion incidence was higher than for the controls in the F. culmorum and $F$. pseudograminearum treatments at both locations during both years (data not shown). During 2004, B. sorokiniana increased the incidence of lesions only at Pendleton (data not shown).

Disease severity on subcrown internodes was increased only by $F$. pseudograminearum at Moro when data were grouped over years for each location (Table 3). However, when individual experiments were analyzed, all three pathogens increased lesion severity at Moro and Pendleton during 2003 (data not shown), with F. pseudograminearum having a higher severity index than the other two pathogens. None of the pathogens significantly increased the severity index during 2004 (data not shown).

Incidence of plants with rotted crowns was increased by $F$. pseudograminearum at both locations (Table 3). Percentages of plants with rotted crowns were higher for $F$. pseudograminearum than other treatments at Moro and Pendleton during both years (data not shown). At Pendleton, the crown rot incidence for $B$. sorokiniana and $F$. culmorum also was higher than the control during 2003 but not during 2004 (data not shown).

Head density and whiteheads. Each of the three pathogen treatments reduced the density of mature plant heads at Moro (Table 3), with $F$. pseudograminearum having a greater negative impact than $B$. sorokiniana and $F$. culmorum. Density of heads was greater $(P<0.05)$ during 2004 than 2003 (data not shown), likely due to differences in rainfall. At Pendleton, head density was reduced by $F$. culmorum and $F$. pseudograminearum (Table 3), with the differences being of statistical significance $(P<0.05)$ only during 2003 (data not shown).

Percentages of whiteheads were increased by $F$. pseudograminearum at Moro and by $F$. culmorum and $F$. pseudograminearum at Pendleton (Table 3). Whiteheads were prevalent during both years at the lowest rainfall location (Moro) and only during the driest year (2003) at the highest rainfall location (Pendleton) (data not shown).

Grain yield. Grain yields in control treatments during 2003 and 2004 were 1,431 and 3,398 $\mathrm{kg} / \mathrm{ha}$ at Moro and 2,026 and $3,819 \mathrm{~kg} / \mathrm{ha}$ at Pendleton (data not shown). Yield was not reduced by $B$. sorokiniana during either year (Fig. 2). When the 2 years were grouped, inoculation of soil with $F$. culmorum reduced yield at

Table 2. Seedling establishment, disease incidence, disease severity, and grain yield for 'Zak' spring wheat at Moro and Pendleton, Oregon during 2003 and $2004^{\mathrm{z}}$

\begin{tabular}{|c|c|c|c|c|c|c|c|c|}
\hline ANOVA & df & $\begin{array}{l}\text { Stand density } \\
\text { (plants/m) }\end{array}$ & $\begin{array}{c}\text { SCI incidence } \\
(\%)\end{array}$ & $\begin{array}{c}\text { SCI severity } \\
(0-4)\end{array}$ & $\begin{array}{c}\text { Rotted } \\
\text { crowns }(\%)\end{array}$ & $\begin{array}{c}\text { White-heads } \\
(\%)\end{array}$ & $\begin{array}{l}\text { Head density } \\
\quad(\text { heads/m) }\end{array}$ & $\begin{array}{c}\text { Grain yield } \\
\text { (kg/ha) }\end{array}$ \\
\hline Blocks & 25 & ns & ns & ns & ns & ns & ns & $* * *$ \\
\hline \multicolumn{9}{|l|}{ Main effects } \\
\hline Location & 1 & $* * *$ & $* * *$ & $*$ & ns & ns & $* * *$ & $* * *$ \\
\hline Year & 1 & $* *$ & ns & ns & ns & $* * *$ & $* * *$ & $* * *$ \\
\hline Pathogen & 3 & ns & $* * *$ & $*$ & $* * *$ & $* * *$ & $\mathrm{~ns}$ & $* * *$ \\
\hline \multicolumn{9}{|l|}{ Interaction } \\
\hline Location-year & 1 & ns & ns & ns & ns & $* * *$ & ns & ns \\
\hline Location-pathogen & 3 & ns & ns & ns & ns & $\mathrm{ns}$ & ns & $* * *$ \\
\hline Year-pathogen & 3 & ns & ns & ns & ns & $*$ & $*$ & ns \\
\hline Location-year-pathogen & 3 & $*$ & $*$ & ns & ns & $* * *$ & $*$ & $* * *$ \\
\hline Error & 159 & $\ldots$ & $\ldots$ & $\ldots$ & $\ldots$ & $\ldots$ & $\ldots$ & $\ldots$ \\
\hline Total & 199 & $\ldots$ & $\ldots$ & $\ldots$ & $\ldots$ & $\ldots$ & $\ldots$ & $\ldots$ \\
\hline \multicolumn{9}{|l|}{ Means for main effects } \\
\hline \multicolumn{9}{|l|}{ Location } \\
\hline Moro & $\ldots$ & $20 \mathrm{a}$ & $17 \mathrm{a}$ & $1.0 \mathrm{a}$ & $2.7 \mathrm{a}$ & $1.0 \mathrm{a}$ & $79 \mathrm{a}$ & $2,196 \mathrm{a}$ \\
\hline Pendleton & $\ldots$ & $41 \mathrm{~b}$ & $32 \mathrm{~b}$ & $1.3 \mathrm{~b}$ & $3.2 \mathrm{a}$ & $0.9 \mathrm{a}$ & $101 \mathrm{~b}$ & $2,722 b$ \\
\hline $\mathrm{LSD}_{0.05}$ & $\ldots$ & 3 & 5 & 0.2 & $\ldots$ & $\ldots$ & 5 & 102 \\
\hline \multicolumn{9}{|l|}{ Year } \\
\hline 2003 & $\ldots$ & $33 \mathrm{a}$ & $23 \mathrm{a}$ & $1.1 \mathrm{a}$ & $2.6 \mathrm{a}$ & $1.3 \mathrm{a}$ & $83 \mathrm{a}$ & $1,639 \mathrm{a}$ \\
\hline 2004 & $\ldots$ & $28 \mathrm{~b}$ & $26 \mathrm{a}$ & $1.2 \mathrm{a}$ & $3.3 \mathrm{a}$ & $0.6 \mathrm{~b}$ & $97 \mathrm{~b}$ & $3,279 \mathrm{~b}$ \\
\hline $\mathrm{LSD}_{0.05}$ & $\ldots$ & 3 & $\ldots$ & $\ldots$ & $\ldots$ & 0.2 & 5 & 102 \\
\hline \multicolumn{9}{|l|}{ Pathogen } \\
\hline Control & $\ldots$ & $33 \mathrm{a}$ & $17 \mathrm{a}$ & $1.0 \mathrm{a}$ & $1.1 \mathrm{a}$ & $0.7 \mathrm{a}$ & $92 \mathrm{a}$ & $2,561 \mathrm{a}$ \\
\hline B. sorokiniana & $\ldots$ & $31 \mathrm{a}$ & $26 \mathrm{~b}$ & $1.2 \mathrm{ab}$ & $1.0 \mathrm{a}$ & $0.6 \mathrm{a}$ & $94 \mathrm{a}$ & $2,533 \mathrm{ab}$ \\
\hline F. culmorum & $\ldots$ & $28 \mathrm{a}$ & $28 \mathrm{~b}$ & $1.1 \mathrm{ab}$ & $1.9 \mathrm{a}$ & $1.2 \mathrm{~b}$ & $87 \mathrm{a}$ & $2,359 \mathrm{bc}$ \\
\hline F. pseudograminearum & $\ldots$ & $29 \mathrm{a}$ & $37 \mathrm{c}$ & $1.5 \mathrm{~b}$ & $9.1 \mathrm{~b}$ & $1.5 \mathrm{c}$ & $85 \mathrm{a}$ & $2,256 \mathrm{c}$ \\
\hline $\mathrm{LSD}_{0.05}$ & $\ldots$ & $\ldots$ & 9 & 0.5 & 4.0 & 0.4 & $\ldots$ & 202 \\
\hline
\end{tabular}

${ }^{\mathrm{z}}$ Means represent data pooled over two locations and two years. Four pathogen treatments consisted of soils naturally infested with a non-quantified native population of Fusarium pseudograminearum (control) supplemented with additional inoculum of Bipolaris sorokiniana, F. culmorum or F. pseudograminearum. $\mathrm{SCI}=$ subcrown internode lesions and ANOVA $=$ analysis of variance (three-way randomized block). Level of significance: ns $=$ not significant $(P>0.05) ; * * *$, and $* * *=P<0.05,0.01$, and 0.001 , respectively. Means for each main treatment effect followed by the same letter within a column are not significantly different at $P=0.05$ according to Fisher's least significant difference (LSD) test. 
both locations and F. pseudograminearum reduced yield at Moro (Table 3 ). The effect of year on yield was significant at both locations and the pathogen-year interaction was significant for yields at Pendleton (Table 3). Inoculation with F. culmorum reduced spring wheat yield during 2003 and 2004 by 15 and $8 \%$, respectively, at Moro and by 15 and $10 \%$ at Pendleton (Fig. 2). F. pseudograminearum reduced yield by about $25 \%$ each year at Moro and by $15 \%$ at Pendleton during 2003 (Fig. 2).

Grain test weight and kernel weight averaged $755 \mathrm{~kg} / \mathrm{m}^{3}$ and $31.4 \mathrm{mg}$, respectively. These values varied for years and locations but were not significantly affected by inoculation with the three crown rot pathogens (data not shown).

Yield during both years at Moro was significantly inversely correlated with incidence of subcrown internode lesions and with percentages of rotted crowns and whiteheads, and directly correlated with numbers of heads per meter of row. These measures of crown rot incidence and severity were inversely correlated with yield at Pendleton only during 2003. Yield components such as heads per meter of row and kernel weight but not measures of disease were significantly correlated with yield at Pendleton during 2004.

Variability among isolates: Seedling emergence. At Moro, stand was reduced by one B. sorokiniana isolate during 2003 and by three isolates during 2004 (Fig. 3). The $B$. sorokiniana isolate that reduced stand during 2003 did not do so during 2004. Four of eight $F$. culmorum isolates reduced stand at Moro during 2003 and seven of eight isolates did so during 2004. Of $11 F$. pseudograminearum isolates, 8 reduced stand at Moro during 2003 and 2004 but only 6 isolates were consistent in reducing stand both years.

At Pendleton, three of five $B$. sorokiniana isolates reduced stand during both 2003 and 2004, but only two of the isolates reduced stand each year (Fig. 4). Four of eight $F$. culmorum isolates reduced stand during 2003 and 2004, but only one isolate was consistent in reducing stand both years. Of $11 \mathrm{~F}$. pseudograminearum isolates, 3 reduced stand during 2003 and 6 isolates did so during 2004, but none of the isolates were consistent in reducing stand both years.

Several isolates of $B$. sorokiniana, $F$. culmorum, and $F$. pseudograminearum appeared to increase stand establishment compared with the composite control (26 replicates) during 2003 and 2004 (Figs. 3 and 4). This relationship was never statistically significant when data were analyzed as a split-plot design.

Variability among isolates: Disease incidence and severity. Isolates of each pathogen were variable in causing lesion

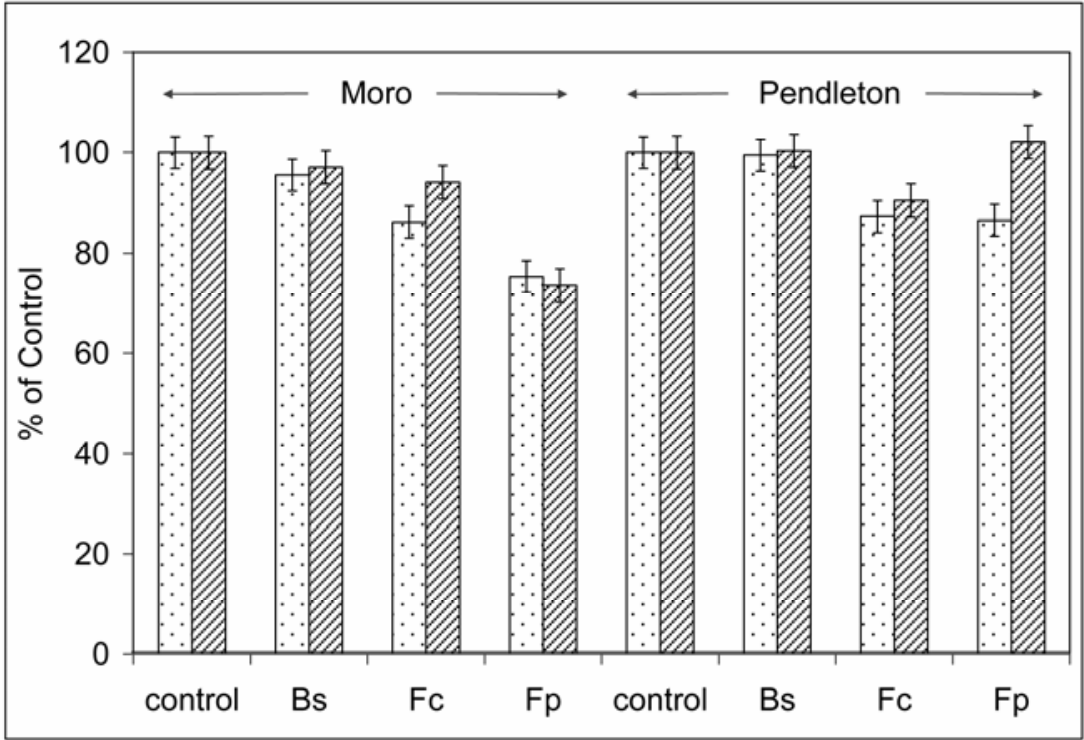

Fig. 2. Influence of three crown rot pathogens on percentage of yield of spring wheat $\mathrm{cv}$. Zak at Moro and Pendleton during 2003 (dotted bars) and 2004 (slashed bars) compared with noninoculated controls; error bars indicate differences $(P>0.05)$ among treatments for the average of 5 isolates of Bipolaris sorokiniana $(\mathrm{Bs}), 8$ isolates of Fusarium culmorum $(\mathrm{Fc})$, and 11 isolates of F. pseudograminea$\operatorname{rum}(\mathrm{Fp})$.

Table 3. Seedling establishment, disease incidence and severity, and yield components for 'Zak' spring wheat at Moro (M) and Pendleton (P), Oregon during 2003 and $2004^{x}$

\begin{tabular}{|c|c|c|c|c|c|c|c|c|c|c|}
\hline \multirow[b]{2}{*}{ Sampling parameter ${ }^{y}$} & \multirow[b]{2}{*}{ Location } & \multicolumn{4}{|c|}{ Inoculum treatment } & \multicolumn{3}{|c|}{$\mathbf{F}>\boldsymbol{P}$} & \multicolumn{2}{|c|}{$\mathbf{L S D}_{0.05}$} \\
\hline & & Control & Bs & Fc & $\mathbf{F p}$ & Pathogen & Year & Pathogen-year & Pathogen & Year \\
\hline \multirow[t]{2}{*}{ Seedlings/m of row } & M & $22.5 \mathrm{a}$ & $21.5 \mathrm{ab}$ & $16.7 \mathrm{~b}$ & $16.7 \mathrm{~b}$ & $* *$ & ns & ns & 5.0 & $\ldots$ \\
\hline & $\mathrm{P}$ & $42.7 \mathrm{a}$ & $39.5 \mathrm{a}$ & $39.2 \mathrm{a}$ & $40.4 \mathrm{a}$ & ns & $* * *$ & $*$ & $\ldots$ & 3.9 \\
\hline \multirow[t]{2}{*}{ SCI incidence (\%) } & M & $9.4 \mathrm{~b} a$ & $16.0 \mathrm{ab}$ & $18.1 \mathrm{bc}$ & $28.2 \mathrm{c}$ & $* * *$ & $* *$ & ns & 10.6 & 5.6 \\
\hline & $\mathrm{P}$ & $23.2 \mathrm{a}$ & $36.0 \mathrm{~b}$ & $37.5 \mathrm{~b}$ & $45.5 \mathrm{~b}$ & $* *$ & ns & ns & 11.7 & $\ldots$ \\
\hline \multirow[t]{2}{*}{ SCI severity } & M & $0.9 \mathrm{a}$ & $1.1 \mathrm{a}$ & $0.9 \mathrm{a}$ & $1.5 \mathrm{~b}$ & $*$ & ns & $\mathrm{ns}$ & 0.3 & $\ldots$ \\
\hline & $\mathrm{P}$ & $1.2 \mathrm{a}$ & $1.5 \mathrm{a}$ & $1.3 \mathrm{a}$ & $1.5 \mathrm{a}$ & ns & ns & ns & $\ldots$ & $\ldots$ \\
\hline \multirow[t]{2}{*}{ Plants with rotted crowns (\%) } & M & $1.5 \mathrm{a}$ & $1.0 \mathrm{a}$ & $1.3 \mathrm{a}$ & $9.6 \mathrm{~b}$ & $* * *$ & ns & $\mathrm{ns}$ & 6.2 & $\ldots$ \\
\hline & $\mathrm{P}$ & $0.4 \mathrm{a}$ & $1.3 \mathrm{a}$ & $2.5 \mathrm{a}$ & $8.6 \mathrm{~b}$ & $* * *$ & ns & ns & 4.6 & $\ldots$ \\
\hline \multirow[t]{2}{*}{ Mature heads/m of row } & M & $104 \mathrm{a}$ & $83 \mathrm{~b}$ & $81 \mathrm{~b}$ & $71 \mathrm{c}$ & $* *$ & $* * *$ & ns & 10 & 5 \\
\hline & $\mathrm{P}$ & $124 \mathrm{a}$ & $109 \mathrm{ab}$ & $96 \mathrm{~b}$ & $99 \mathrm{~b}$ & $*$ & $* * *$ & $* *$ & 21 & 7 \\
\hline \multirow[t]{2}{*}{ Whiteheads (\% of heads) } & M & $0.8 \mathrm{a}$ & $0.7 \mathrm{a}$ & $1.0 \mathrm{a}$ & $1.7 \mathrm{~b}$ & $* *$ & ns & ns & 0.6 & $\ldots$ \\
\hline & $\mathrm{P}$ & $0.7 \mathrm{a}$ & $0.4 \mathrm{a}$ & $1.3 \mathrm{~b}$ & $1.4 \mathrm{~b}$ & $* * *$ & ns & ns & 0.3 & $\ldots$ \\
\hline \multirow[t]{2}{*}{ Grain yield (kg/ha) } & M & $2,415 \mathrm{a}$ & $2,320 \mathrm{ab}$ & $2,148 \mathrm{~b}$ & $1,789 \mathrm{c}$ & $* * *$ & $* * *$ & ns & 248 & 111 \\
\hline & $\mathrm{P}$ & $2,923 \mathrm{a}$ & $2,916 \mathrm{a}$ & $2,633 b$ & $2,782 \mathrm{ab}$ & $*$ & $* * *$ & $* *$ & 206 & 165 \\
\hline \multirow[t]{2}{*}{ Test weight $\left(\mathrm{kg} / \mathrm{m}^{3}\right)$} & M & $758 \mathrm{a}$ & $759 a$ & $756 a$ & $762 \mathrm{a}$ & ns & $* * *$ & ns & $\ldots$ & 6 \\
\hline & $\mathrm{P}$ & $753 \mathrm{a}$ & $742 \mathrm{a}$ & $752 \mathrm{a}$ & $751 \mathrm{a}$ & ns & $* * *$ & ns & $\ldots$ & 5 \\
\hline \multirow[t]{2}{*}{ Kernel weight (mg) } & M & $31 \mathrm{a}$ & $30 \mathrm{a}$ & $32 \mathrm{a}$ & $31 \mathrm{a}$ & ns & $-^{\mathrm{z}}$ & $\ldots$ & $\ldots$ & $\ldots$ \\
\hline & $\mathrm{P}$ & $31 \mathrm{a}$ & $30 \mathrm{a}$ & $31 \mathrm{a}$ & $32 \mathrm{a}$ & ns & $* *$ & $*$ & $\ldots$ & 1 \\
\hline
\end{tabular}

${ }^{\mathrm{x}}$ Means represent data pooled over two years for each location. Soils naturally infested with a non-quantified native population of Fusarium pseudo graminearum (control) received additional inoculum of Bipolaris sorokiniana (Bs), F. culmorum (Fc) or F. pseudograminearum (Fp). Means for control and inoculated treatments followed by the same letter within a row are not significantly different at $P=0.05$ according to Fisher's least significant difference $(\mathrm{LSD}) ; \mathrm{ns}=$ not significant $(P>0.05) ; *$, **, and $* * *=P<0.05,0.01$, and 0.001 , respectively.

y $\mathrm{SCI}=$ subcrown internode lesions; severity on a scale of 1 to 4 , where $4=$ severe.

${ }^{\text {z }}$ Kernel weight was measured only during 2003. 
development on subcrown internodes in individual experiments (data not shown). Over the four site-years of testing, 4 of 5 B. sorokiniana isolates, 6 of $8 F$. culmorum isolates, and 11 of $11 \mathrm{~F}$. pseudograminearum isolates were associated with lesion incidence higher than the control in at least one experiment. However, isolates rarely were consistent in this association when compared among experiments. Lesion incidence was higher than for the control at Pendleton for three of five $B$. sorokiniana isolates during 2003 and two isolates during 2004. At Moro, four $B$. sorokiniana isolates increased lesion incidence during 2004 and none did so during
2003. Lesion incidence was increased by three of eight $F$. culmorum isolates during 2004 and by one during 2003. At Pendleton, six $F$. culmorum isolates increased lesion incidence during 2003 and only three did so during 2004. Of $11 \mathrm{~F}$. pseudograminearum isolates, 7 increased lesion incidence at Moro during 2003 and 2004 and 8 of $11 F$. pseudograminearum isolates increased lesion incidence each year at Pendleton.

Severity indices for individual isolates of the three pathogens closely followed patterns discussed for lesion incidence (data not shown).

Association of individual isolates with the crown rotting symptom also was highly variable over locations and years (data not shown). Over the four site-years of testing, 2 of $5 \mathrm{~B}$. sorokiniana isolates, 4 of $8 \mathrm{~F}$. culmorum isolates, and 10 of $11 \mathrm{~F}$. pseudograminearum isolates were associated with crown rot symptoms in at least one experiment. Only one B. sorokiniana isolate was associated with crown infection during 2004 at Moro and Pendleton, and the identity of the isolate differed for these locations. Two F. culmorum isolates were associated with crown rot symptoms at Pendleton during 2003 and a single different isolate was associated during 2004. At Moro, crown rot occurred in response to inoculation with two F. culmorum isolates,
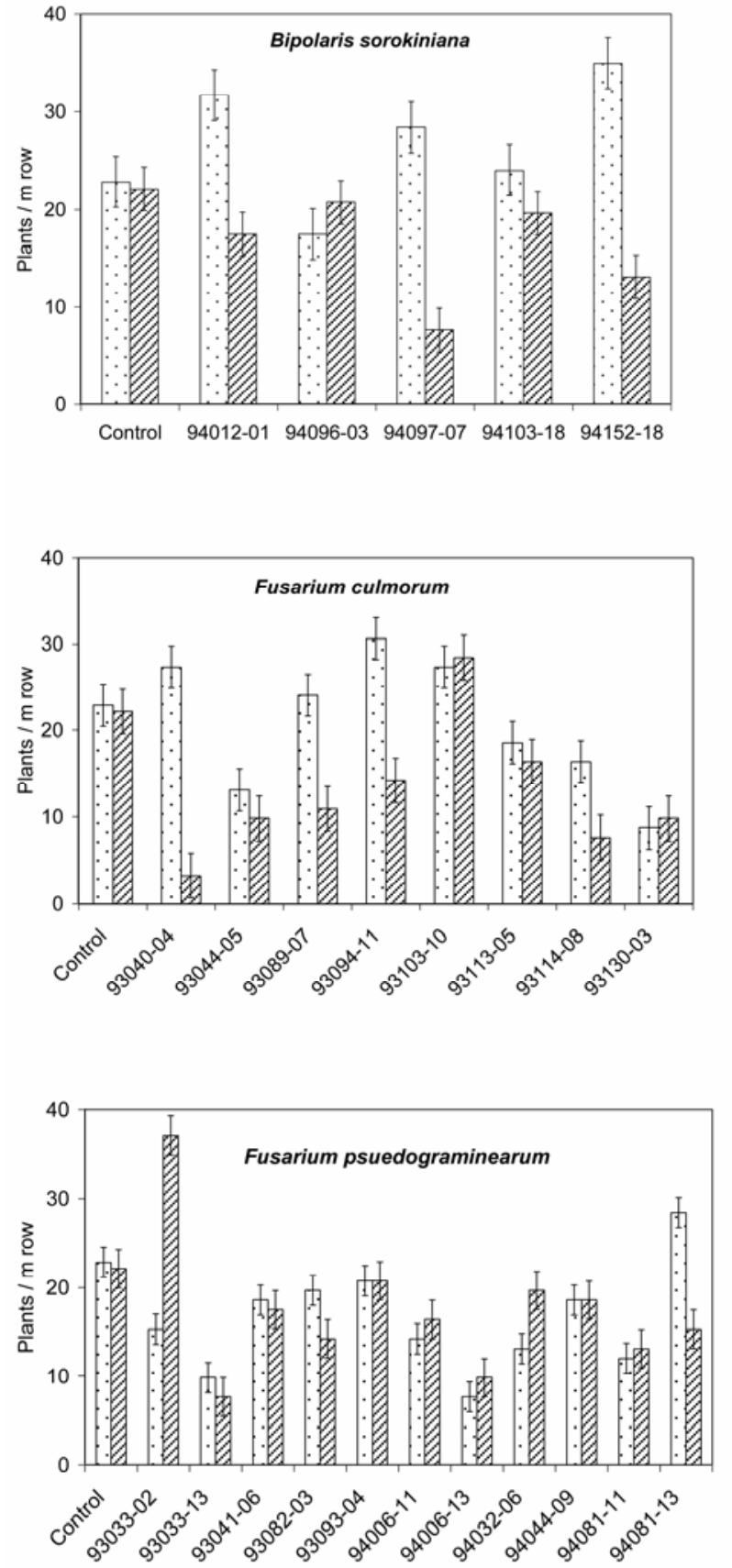
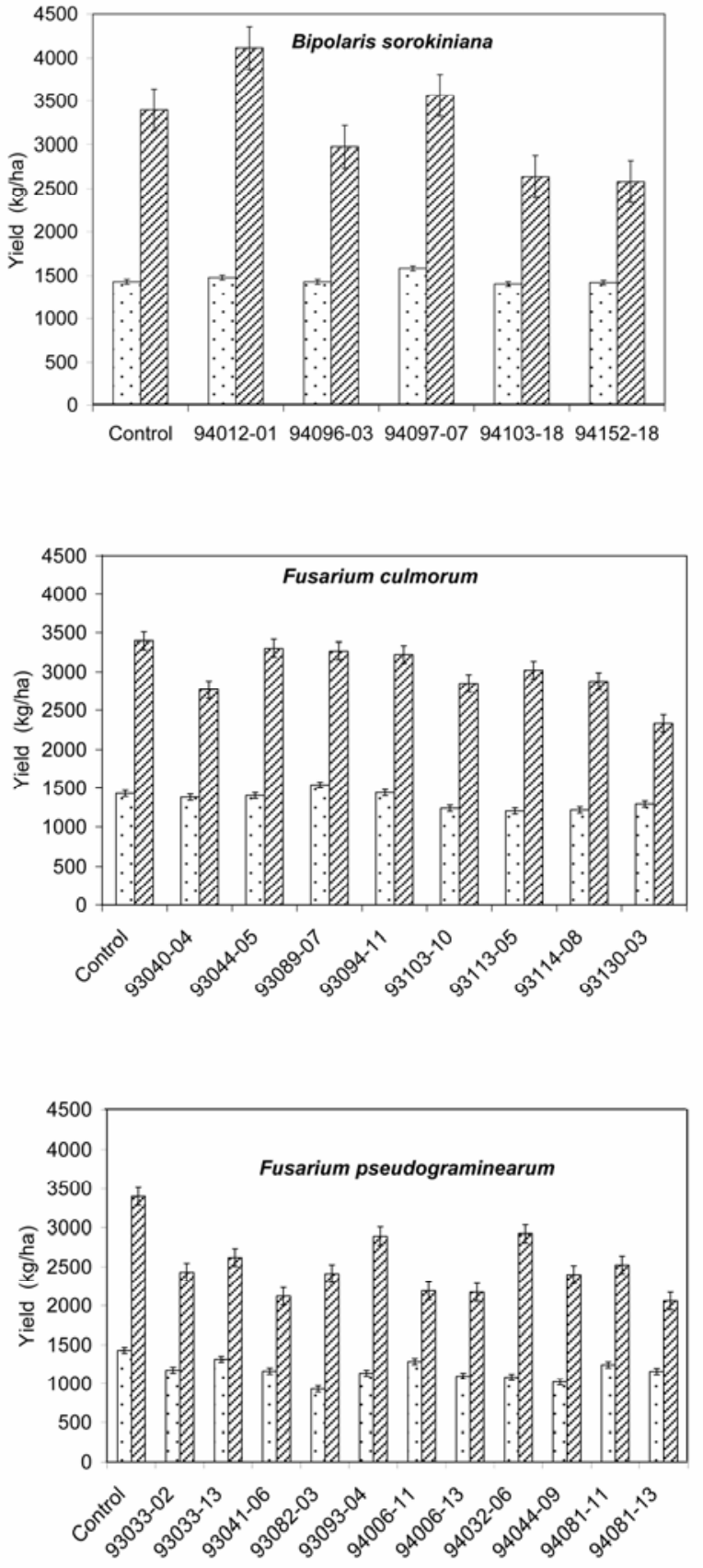

Fig. 3. Influence of three crown rot pathogens on seedling stand and yield of spring wheat cv. Zak at Moro during 2003 (dotted bars) and 2004 (slashed bars); error bars indicate differences $(P>0.05)$ among control treatments (summed over 15 replicates) and individual isolates of Bipolaris sorokiniana $(n=$ 5), Fusarium culmorum $(n=8)$, and $F$. pseudograminearum $(n=11)$. 
one of which also led to crown rot at Pendleton. During 2003, rotted crowns were associated with three and two isolates of $F$. pseudograminearum at Moro and Pendleton, respectively, with one isolate having this association at both locations. During 2004 , seven and five $F$. pseudograminearum isolates were associated with crown rot at Moro and Pendleton, respectively, and only three isolates were consistent between locations. With one exception at each location, different isolates of $F$. pseudograminearum were associated with crown rot during 2003 than during 2004.

Variability among isolates: Grain yield. Isolates of each species were highly variable for effects on grain yield at Moro (Fig. 3) and Pendleton (Fig. 4). Over the four site-years of testing, four of five $B$. sorokiniana isolates and all isolates of $F$. culmorum and $F$. pseudograminearum were associated with reduced yield in at least one experiment. However, no B. sorokiniana isolates were associated with reduced yield during 2003 and only three were associated with reduced yield at both locations during 2004. Only two F. culmorum isolates (93113-03 and 93130-03) were associated with reduced yield in all four experiments (Figs. 2 and 3). Two $F$. culmorum isolates (93044-05 and 9309411) reduced yields both years at Pendleton (Fig. 4) but did not reduce yields at Moro (Fig. 3). Conversely, two F. culmorum isolates (93103-10 and 93114-08) reduced yields both years at Moro (Fig. 3) but reduced yields at Pendleton only during 2004 (Fig. 4). All F. pseudograminearum isolates were associated with reduced yield each year at Moro (Fig. 3). At Pendleton, eight and three $F$. pseudograminearum isolates were associated with reduced yield during 2003 and 2004, respectively. At Pendleton, only one isolate (93093-04) was not associated with reduced yield (Fig. 4) or with higher disease incidence or severity during at least 1 year (data not shown).

\section{DISCUSSION}

F. culmorum and F. pseudograminearum are considered the most important crown rot species on wheat in the PNW $(8,29)$ and in other regions of the world with comparable temperate semiarid climates with winter-dominant distribution of rainfall $(5,6,19)$. Also associated with the crown rot complex in many regions are the common root rot pathogen $B$. sorokiniana and other species such as $F$. avenaceum
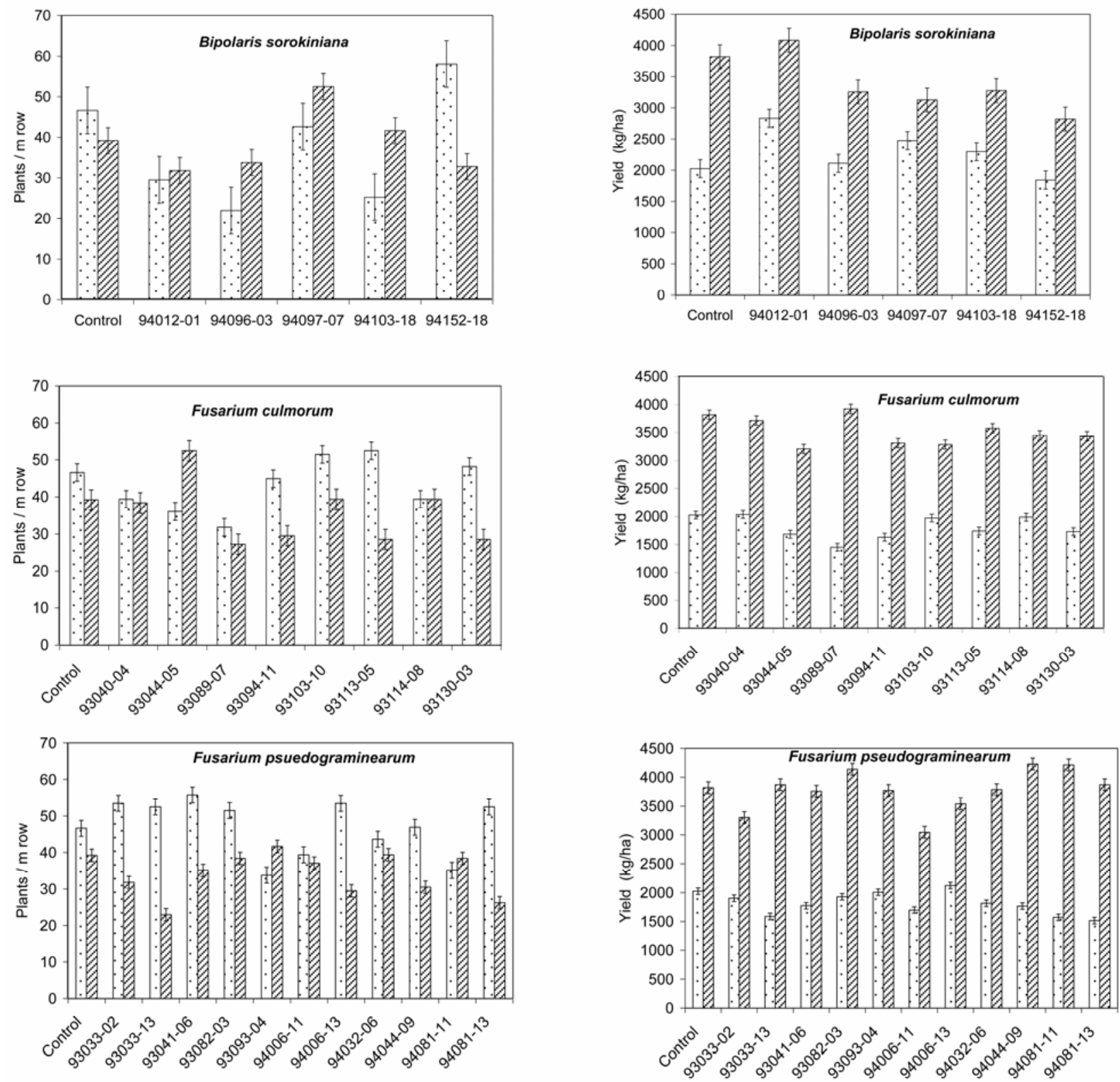

Fig. 4. Influence of three crown rot pathogens on seedling stand and yield of spring wheat cv. Zak at Pendleton during 2003 (dotted bars) and 2004 (slashed bars); error bars indicate differences $(P>0.05)$ among control treatments (summed over 15 replicates) and individual isolates of Bipolaris sorokiniana $(n=$ 5), Fusarium culmorum $(n=8)$, and $F$. pseudograminearum $(n=11)$. 
and $M$. nivale $(4,5,10,13,19)$. Nearly all of these determinations are based on the frequency of isolations from wheat in commercial fields. Pathogenic capabilities for these species also have been reported $(1,4,5,7,10,12-14,19,25)$.

In the present study, we evaluated disease symptoms and wheat growth in soils infested with the five above-named crown rot species isolated from crown rotaffected wheat in eastern Oregon and Washington. Each of the five species reduced growth of wheat plants in the greenhouse. Growth was progressively more limited in the order B. sorokiniana $<M$. nivale $<F$. culmorum $<F$. avenaceum $<F$. pseudograminearum. Negative correlations between disease symptom ratings and plant height were significant $(P<0.05)$ for the three Fusarium spp., indicating the potential for $F$. avenaceum to be an important member of the pathogen complex in regions where this species is present. Cook (8) initially described $F$. avenaceum as a member of the complex in the PNW but considered this species much less important than $F$. culmorum and $F$. pseudograminearum, based on much lower isolation frequencies and mortality of plants infected with $F$. avenaceum. In the same region, Smiley and Patterson (29) confirmed the lower isolation frequency for $F$. avenaceum compared with $F$. culmorum and $F$. pseudograminearum. Plants infected by $F$. avenaceum in greenhouse tests reported in this article were not grown to maturity but limited seedling growth in much the same manner as F. culmorum and $F$. pseudograminearum. Compared with $F$. culmorum and $F$. graminearum, $F$. avenaceum generally is more abundant in environments higher in rainfall than most of the primary wheat-producing regions of Oregon and Washington (8). However, the isolation frequency varied greatly over 2 years of a crown rot survey (29), with a sixfold higher detection rate during a wet than a dry year in the main wheatproduction regions of Oregon and Washington. $F$. avenaceum also retains pathogenicity at lower temperatures than $F$. culmorum and $F$. graminearum (4). It appears possible that the importance of $F$. avenaceum in the crown rot complex may differ greatly from year to year in the PNW. This possibility needs to be re-evaluated under dryland field conditions contrasting years with above- and below-average precipitation.

Four field experiments were performed over two seasons with 24 isolates of $F$. pseudograminearum, $F$. culmorum, and $B$. sorokiniana. All three species caused severe disease and reduced grain yield in at least one field experiment. F. pseudograminearum was the most pathogenic species examined and was the crown rot fungus isolated most frequently from wheat in commercial fields across the PNW (29). F. culmorum also was highly pathogenic and is the dominant crown rot fungus present in fewer regions or years compared with $F$. pseudograminearum. B. sorokiniana reduced yield in fewer experiments but occasionally is considered the dominant crown rot organism in the PNW (29). Overall, F. culmorum and $F$. pseudograminearum caused measures of disease to be increased and plant growth and yield to be reduced more frequently than B. sorokiniana. For instance, F. culmorum and $F$. pseudograminearum were the only species that reduced seedling stands, increased the expression of whiteheads in maturing crops, and reduced the yield of spring wheat. Fernandez and Chen (13) also reported that $F$. culmorum and $F$. graminearum generally were more aggressive crown rot pathogens than B. sorokiniana under greenhouse conditions.

Development of whiteheads and reduction in grain yield were greater during the driest year and at the driest location. These results are consistent with previous reports that crown rot damage is greatest when plants are subjected to water stress near the end of the growing season $(16,23,24$, 28,31,34).

Pathogenic variation among isolates is recognized for species associated with the crown rot complex $(12,25,36)$ but had not been reported for isolates from the PNW. We found that a high level of variation also exists among isolates for each species in the PNW. Random selections of inoculum groups containing only a few isolates are likely to result in very different conclusions. Recognition and management of high variability among isolates is likely to be most important for investigating the relative impact of crown rot pathogens on resistance or tolerance of wheat (20).

Variability among isolates for Fusarium spp. affecting small grain crops is best understood for Fusarium head blight $(20,21,36)$. However, Fernandez and Chen (13) demonstrated that these fungi generally lack adaptation for aggressiveness to specific plant tissues, resulting in comparable attributes for causing both head blight and crown rot. In contrast, with our greenhouse tests, seedling tests by Fernandez and Chen (13) indicated that $F$. avenaceum was less pathogenic than $F$. culmorum. Differences in relative rankings among $F$. avenaceum and $F$. culmorum in these experiments may relate to differences in day length and incubation temperatures: a 16-h photoperiod and day and night temperatures of 22 and $15^{\circ} \mathrm{C}$, respectively, for tests reported by Fernandez and Chen (13), and an 8-h photoperiod and day and night temperatures of 18 and $13^{\circ} \mathrm{C}$, respectively, for our experiment.

Variability among isolates of $B$. sorokiniana also is well known. Aggressiveness among isolates normally is distributed within populations for each region (12). It is especially instructive that Roginskaya (25) reported that $B$. sorokiniana isolates from East Siberia caused a range of wheat growth responses from $70 \%$ reduction to $12 \%$ increase in plant weight, and that the ratio of isolates with low, intermediate, and high levels of pathogenicity within the population differed among regions. In the present study, we found individual isolates of all crown rot species that periodically resulted in measures of growth or yield greater than the highest range for individual replicates in the controls. Further, Roginskaya (25) observed that each isolate caused external symptoms of infection but caused variable pathogenicity, mainly through variation in progression of the disease process. It was concluded that careful attention based on known attributes must be used to choose isolates for artificial inoculations. Smiley et al. (28) reported winter wheat yields reduced as much as $61 \%$ following inoculation with a mixture of five $F$. pseudograminearum isolates (93082-03, 94006-13, 94032-06, 94044-09, and 94081-11). In the present experiments, these isolates led to stand establishments both higher and lower than for the mean of control treatments at Pendleton but not Moro (Figs. 2 and 3). These isolates each caused reduced yield at Moro during both years and at Pendleton during the driest year (2003), but led to yield responses both higher and lower than the control at Pendleton during the wettest year (2004). These observations emphasize the need for selecting isolates for use in inoculation studies that include a wide range of pathogenic capabilities representative of isolate variability in the native population.

Additionally, it is conceivable that interand intraspecies response to environmental variation exists coincident to environmental influence on crown rot incidence and severity (24). If so, this could assist in explaining shifts in dominance among crown rot species revealed during surveys of wheat conducted over sequential years $(19,24,29)$. Additional research is needed to assess environmental influences on individual isolates for each of the important crown rot species in the PNW.

\section{ACKNOWLEDGMENTS}

We thank K. Rhinhart and E. Jacobsen, farm managers at Oregon State University research centers at Pendleton and Moro, respectively, and temporary employees J. Jackson and T. Zeckman for their technical assistance.

\section{LITERATURE CITED}

1. Arseniuk, E., Goral, T., and Czembor, H. J. 1993. Reaction of triticale, wheat and rye accessions to graminaceous Fusarium spp. infection at the seedling and adult plant growth stages. Euphytica 70:175-183.

2. Backhouse, D., Abubakar, A. A., Burgess, L. W., Dennis, J. I., Hollaway, G. J., Wildermuth G. B., Wallwork, J., and Henry, F. J. 2004 Survey of Fusarium species associated with crown rot of wheat and barley in eastern Australia. Australas. Plant Pathol. 33:255-261.

3. Backhouse, D., and Burgess, L. W. 2002. Climatic analysis of the distribution of Fusa 
rium graminearum, $F$. pseudograminearum and F. culmorum on cereals in Australia. Australas. Plant Pathol. 31:321-327.

4. Brennan, J. M., Fagan, B., van Maanen, A., Cooke, B. M., and Doohan, F. M. 2003. Studies on in vitro growth and pathogenicity of European Fusarium fungi. Eur. J. Plant Pathol. 109:577-587.

5. Burgess, L. W., Backhouse, D., Summerell, B. A., and Swan, L. J. 2001. Crown rot of wheat. Pages. 271-294 in: Fusarium. B. A. Summerell, J. F. Leslie, D. Backhouse, W. L. Bryden, and L. W. Burgess, eds. American Phytopathological Society Press, St. Paul, MN.

6. Burgess, L. W., Dodman, R. L., Pont, W., and Mayers, P. 1981. Fusarium diseases of wheat, maize and grain sorghum in eastern Australia. Pages 64-76 in: Fusarium: Diseases, Biology and Taxonomy. P. E. Nelson, T. A. Toussoun, and R. J. Cook, eds. The Pennsylvania State University Press, University Park.

7. Cassini, R. 1981. Fusarium diseases of wheat and corn in western Europe. Pages 56-63 in: Fusarium: Diseases, Biology and Taxonomy. P. E. Nelson, T. A. Toussoun, and R. J. Cook, eds. The Pennsylvania State University Press, University Park.

8. Cook, R. J. 1968. Fusarium root and foot rot of cereals in the Pacific Northwest. Phytopathology 58:127-131.

9. Cook, R. J. 1980. Fusarium foot rot of wheat and its control in the Pacific Northwest. Plant Dis. 64:1061-1066.

10. Cook, R. J. 1981. Fusarium diseases of wheat and other small grains in North America. Pages 39-52 in: Fusarium: Diseases, Biology and Taxonomy. P. E. Nelson, T. A. Toussoun, and R. J. Cook, eds. The Pennsylvania State University Press, University Park.

11. Dodman, R. L., and Wildermuth, G. B. 1987. Inoculation methods for assessing resistance in wheat to crown rot caused by Fusarium graminearum Group 1. Aust. J. Agric. Res. 38:473-486.

12. Duveiller, E., and Garcia Altamirano, I. 2000. Pathogenicity of Bipolaris sorokiniana isolates from wheat roots, leaves and grains in Mexico. Plant Pathol. 49:235-242.

13. Fernandez, M. R., and Chen, Y. 2005. Pathogenicity of Fusarium species on different plant parts of spring wheat under controlled conditions. Plant Dis. 89:164-169.

14. Jenkinson, P., and Parry, D. W. 1994. Isolates of Fusarium species from common broadleaved weeds and their pathogenicity to winter wheat. Mycol. Res. 98:776-780.

15. Kane, R. T., Smiley, R. W., and Sorrells, M. E.
1987. Relative pathogenicity of selected Fusarium species and Microdochium bolleyi to winter wheat in New York. Plant Dis. 71:177-181.

16. Klaasen, J. A., Matthee, F. N., Marasas, W. F. O., and van Schalkwyk, D. J. 1992. Survey of Fusarium species associated with crowns of healthy-head and white-head wheat plants in the southern and western Cape Province. Phytophylactica 24:85-94.

17. Klein, T. A., Burgess, L. W., and Ellison, F. W. 1991. The incidence and spatial patterns of wheat plants infected by Fusarium graminearum Group 1 and the effect of crown rot on yield. Aust. J. Agric. Res. 42:399-407.

18. Marasas, W. F. O., Voight, G. J., Lamprecht, S. C., and Van Wyk, P. S. 1988. Crown rot and head blight of wheat caused by Fusarium graminearum groups 1 and 2 in the southern Cape Province. Phytophylactica 20:385-389.

19. Maric, A. 1981. Fusarium diseases of wheat, maize and grain sorghum in eastern Australia. Pages 77-93 in: Fusarium: Diseases, Biology and Taxonomy. P. E. Nelson, T. A. Toussoun, and R. J. Cook, eds. The Pennsylvania State University Press, University Park.

20. Mesterházy, Á. 1997. Methodology of resistance testing and breeding against Fusarium head blight in wheat and results of the selection. Pages 631-637 in: Cereal Res. Commun.: Proc. 5th Eur. Fusarium Semin. Á. Mesterházy, ed. Cereal Research Institute, Szeged, Hungary.

21. Miedaner, T., Gang, G., Schilling, A. G., and Geiger, H. H. 1997. Aggressiveness and mycotoxin production of populations of Fusarium culmorum and Fusarium graminearum in winter rye. Pages 471-475 in: Cereal Res. Commun.: Proc. 5th Eur. Fusarium Semin. Á. Mesterházy, ed. Cereal Research Institute, Szeged, Hungary.

22. Nelson, P. E., Toussoun, T. A., and Marasas, W. F. O. 1983. Fusarium Species: An Illustrated Manual for Identification. The Pennsylvania State University Press, University Park.

23. Papendick, R. I., and Cook, R. J. 1974. Plant water stress and development of Fusarium foot rot in wheat subjected to different cultural practices. Phytopathology 64:358-363.

24. Pettitt, T. R., and Parry, D. W. 2001. Effect of temperature on Fusarium foot rot of wheat. Pages. 145-160 in: Fusarium. B. A. Summerell, J. F. Leslie, D. Backhouse, W. L. Bryden, and L. W. Burgess, eds. American Phytopathological Society Press, St. Paul, MN.

25. Roginskaya, V. A. 1991. Pathogenic variation in East Siberian population of Bipolaris sorokiniana and artificial infection backgrounds. Pages 58-61 in: Proc. First Int. Workshop
Common Root Rot Cereals. R. L. Tinline, K. L. Bailey, L. J. Duczek, and H. Harding, eds. Agriculture Canada Research Station, Saskatoon, Saskatchewan, Canada.

26. Rossi, V., Cervi, C., Chiusa, G., and Languasco, L. 1995. Fungi associated with foot rots on winter wheat in northwest Italy. J. Phytopathol. 143:115-119.

27. Schilling, A. G., Möller, E. M., and Geiger, H H. 1996. Polymerase chain reaction-based assays for species-specific detection of Fusarium culmorum, $F$. graminearum, and $F$. avenaceum. Phytopathology 86:515-522.

28. Smiley, R. W., Gourlie, J. A., Easley, S. A., Patterson, L.-M., and Whittaker, R. G. 2005. Crop damage estimates for crown rot of wheat and barley in the Pacific Northwest. Plant Dis. 89:595-604.

29. Smiley, R. W., and Patterson, L.-M. 1996 Pathogenic fungi associated with Fusarium foot rot of winter wheat in the semiarid Pacific Northwest USA. Plant Dis. 80:944-949.

30. Stack, R. W. 1977. A simple selective medium for isolation of Cochliobolus sativus from diseased cereal crowns and roots. Plant Dis. Rep. 61:521-522.

31. Swan, L. J., Backhouse, D., and Burgess, L. W. 2000. Surface soil moisture and stubble management practice effects on the progress of infection of wheat by Fusarium pseudograminearum. Aust. J. Exp. Agric. 40:693-698.

32. Wearing, A. H., and Burgess, L. W. 1977. Distribution of Fusarium roseum 'Graminearum' Group 1 and its mode of survival in eastern Australian wheat belt soils. Trans. Br. Mycol. Soc. 69:429-442.

33. Wildermuth, G. B., and McNamara, R. B. 1994. Testing wheat seedlings for resistance to crown rot caused by Fusarium graminearum Group 1. Plant Dis. 78:949-953.

34. Wildermuth, G. B., Thomas, G. A., Radford, B. J., McNamara, R. B., and Kelly, A. 1997. Crown rot and common root rot in wheat grown under different tillage and stubble treatments in southern Queensland, Australia. Soil Till. Res. 44:211-224.

35. Williams, K. J., Dennis, J. I., Smyl, C., and Wallwork, H. 2002. The application of speciesspecific assays based on the polymerase chain reaction to analyse Fusarium crown rot of durum wheat. Australas. Plant Pathol. 31:119 127.

36. Xue, A. G., Armstrong, K. C., Voldeng, H. D., Fedak, G., and Babcock, C. 2004. Comparative aggressiveness of isolates of Fusarium spp. causing head blight on wheat in Canada. Can. J. Plant Pathol. 26:81-88. 